\title{
Overall Equipment Effectiveness Improvement with Total Productive Maintenance Method
}

\author{
Claudia Febianny Susilo, Aditya Andika \\ Department of Industrial Engineering \\ Universitas Bina Nusantara \\ Jakarta, Indonesia \\ aditya.a@binus.ac.id
}

\begin{abstract}
This paper discusses the results of a research conducted on the production process of a pharmaceutical product. The product is made by an Indonesian Pharmaceutical company. At the production process, there is a process that is considered not optimal and requires improvement. The process is the packaging processes. The optimization of the packaging process is done by analyzing and proposing the enhancement of Overall Equipment Effectiveness (OEE) value of packaging machine based on Total Productive Maintenance (TPM) method. Based on the analysis, the OEE factor that should be improved is the availability rate. Besides having a low availability rate, the production process of the product frequently did not reach the theoretical targets and there are failures in the packaging materials. Therefore, Failure Mode and Effect Analysis (FMEA) is used as a method to analyze the reject that happens in the packaging processes. In addition, this paper will also use Fishbone Diagram to analyze the causes of the frequent occurrence of the stop line on the production process. Discussions about TPM will be prioritized on several main pillars associated with the aim of improving the OEE.
\end{abstract}

Keywords-Overall Equipment Effectiveness, Total Productive Maintenance, Failure Mode and Effect Analysis, pharmaceutical, packaging

\section{INTRODUCTION}

The effectiveness of the production process is the key in achieving success for a manufacturing company. Therefore, every company that operates in the manufacturing field will always try to improve machine performance or eliminate interference that can hamper the production process. This also applies to an Indonesian Pharmaceutical Company called Company $\mathrm{X}$ (the name of the company is withheld for confidentiality reason) that tries to make improvements in order to optimize the production process of Product $\mathrm{Y}$ (the name of the product is withheld for confidentiality reason). One part of the production process of Product $\mathrm{Y}$ that is considered not optimal is the packaging process where there are problems from the machine and from human factors. Company $\mathrm{X}$ is using OEE Method. The OEE method is used to increase the quality and performance rate and to minimize breakdowns in order to increase the production volume of the organization [1]. Application of the Overall Equipment Effectiveness (OEE) method was conducted to identify the problems and measure the effectiveness of the production process.
OEE assessment is conducted based on the yield and actual time of production compared with the theoretical production time. Failure Mode Effect Analysis (FMEA) will be discussed to evaluate reject of the packaging materials. FMEA method calculates the Risk Priority Number (RPN). It is important to find ways to lower the RPN because lowering the RPN can increase OEE [2]. Fishbone Diagram will be discussed to determine the cause of the stop line on production processes. The Fishbone Diagram is a standardized way of analyzing underlying causes [3].

Generally, OEE value is strongly related to the condition of machines used in production process. Optimal machines conditions will achieve the targeted yield with shorter productions time. Moreover, OEE value is also related to the skill of workers who operate the machine and handle the production process. In order to resolve the issue, it is proposed to apply some of the pillars of the Total Productive Maintenance (TPM) to increase OEE value on packaging process of product $\mathrm{Y}$ in Company X. TPM employs OEE as a quantitative parameter for measuring the performance of a production system [4].

\section{THEORETICAL B ACKGROUND}

\section{A. Failure Mode and Effect Analysis}

FMEA is a systematic approach to analyze, define, estimate, and evaluate risks [5] which combines technology and experience in identifying cause of the failure of the product or the process of planning also eliminate the cause of failure [6]. The results of FMEA are Risk Priority Number (RPN). RPN is a calculated by multiplying the three quantitative rankings based on the information obtained related to the potential failure modes, effects and detection. The RPN will be sorted from the highest rating to suggest improvement actions. Below is a formula for calculating the RPN [7]:

$\mathrm{RPN}=$ Occurrence score $(\mathrm{O}) \times$ Severity score $(\mathrm{S}) \times$ Detection score $(\mathrm{D})$

\section{B. Cause and effect diagram}

Cause and effect or fishbone diagram is known as one of the quality control instruments used to serve the cause of a problem graphically. The cause of the problem of quality is composed by several factors that can generally be 
differentiated by human factor, machinery, capital, methods, and environment. Cause and effect diagram can be used for the needs as follows [8]:

- Identify the cause of a problem.

- Determine the cause of problem and take corrective action.

- Assist in investigating or search further factor.

- Screening analysis methods for problem resolution.

This diagram is used to describe the deviation of quality influenced by a variety of causes that are interconnected.

\section{Overall Equipment Effectiveness}

Overall Equipment Effectiveness (OEE) is a method that used to assess and improve the effectiveness of the machine by removing the six big losses on the production process. The following are descriptions of six big losses, which led to a decrease in productivity in the production [9]:

- Set-up/Adjustment Time is the losses caused by a long time setting.

- Breakdown Losses is due to machine's parts failure where they need to be repaired or replaced.

- Cycle Time Loss is due to the condition of the machine (not working well) and the operator is not efficient.

- Speed Loss is a loss because of a minor stoppage that often happens.

- Startup Loss is a loss caused by an error in the initial set-up that caused the defects.

- Yield Losses happen because of the many defects that occur and cause the raw material is wasted.

The OEE measure is important for the formulation and execution of a TPM improvement strategy [4]. OEE measurement is done by using three main parameters, namely availability, performance, and quality. The world class manufacturing standard of OEE is $85 \%$ [10]. The relationship of the three parameters can be seen in the following formula.

$$
\mathrm{OEE} \%=\mathrm{A} \times \mathrm{P} \times \mathrm{Q} \times 100 \%
$$

\section{Definition:}

$$
\begin{array}{ll}
\mathrm{A} & =\text { Availability Rate } \\
\mathrm{P} & =\text { Performance Rate } \\
\mathrm{Q} & =\text { Quality Rate }
\end{array}
$$

Availability is a ratio that illustrates the use of the time available for the operations of machinery or equipment [11]. The availability rate was influenced by two components that are the breakdown losses and set-up/adjustment time or often called the downtime loss [9]. Availability rate can be calculated by the following formula.

Availability Rate $(\%)=\frac{(\text { Required Availability-Down Time) }}{\text { Required Availability }} \times 100 \%$

Performance is a ratio that illustrates the ability of a machine or equipment in producing goods / products and be seen by the difference in speed of production is ideal and actual production speed [11]. Performance rate is influenced by two components that are speed losses and cycle time [9]. Performance rate can be calculated by the following formula.

Performance Rate $(\%)=\frac{(\text { Optimal cycle time } \times \text { Output })}{\text { Operating time }} \times 100 \%$

Quality rate is a ratio that illustrates the ability of equipment to produce a product that is in accordance with the standard or the ratio of the number of good products to the total number of processed products [11]. Quality rate is influenced by two components, namely the start-up losses and yield losses [9]. Quality rate can be calculated by the following formula.

Quality Rate $(\%)=\frac{\text { (Production Input }- \text { Quality defects) }}{\text { Production input }} \times 100 \%$

\section{Total Productive Maintenance}

Total Productive Maintenance (TPM) is a Japanese philosophy that was developed based on the concept and methodology of productive maintenance. TPM uses an innovative approach to maintenance to optimize the effectiveness of the equipment, reduce breakdowns, and give priority to autonomous maintenance [12]. Basically the application of TPM is done by focusing on eight pillars or elements that help companies to plan, manage, and monitor the process improvements made by the company. Below are the eight pillars of TPM [13]:

- $5 \mathrm{~S}$ (Seiri, Seiton, Seisio, Seiketsu, Shitsuke)

- Autonomous Maintenance

- Kaizen

- Planned Maintenance

- Quality Maintenance

- Training

- Office TPM

- Safety, Health, and Environment 


\section{METHODOLOGY}

Data is collected through field observations, interviews, and focus group discussions. The object of this research is the production process of a pharmaceutical product of an Indonesian Pharmaceutical Company. Due to confidentiality reason, the real name of the company and the product is withheld. In this paper, the company is called "Company X" and the product is called "Product $Y$ ". The members of the production department of Company $\mathrm{X}$ are asked to participate in this study. All of them agreed to participate in interviews and focus group discussions.

Availability, performance, and quality rate data will be processed to obtain the value of the OEE.The results will be analyzed to illustrate the problems faced by companies and to create solutions to the problems.

FMEA have an important role in determine the component that is most critical in causing reject/failure of packaging material. The process of defining the score for Severity $(S)$, Occurrence (O), and Detection (D) of each failure is conducted through a focus group discussion. The range of score for each of the S, O, and D is $1-10$. The $\mathrm{S}, \mathrm{O}$, and D values of the failure modes are gained through a focus group discussion with the members of the production department.

Fishbone diagram is used to analyze the cause of line stop at packaging process of product $\mathrm{Y}$. Fishbone diagram is used because the frequency of line stops which impact on the OEE value that related to adjustment and breakdown losses. The data for developing the fishbone diagram is gathered through discussions with the members of the production department.

After conducting the analysis, improvement suggestions will be made for Company X using the TPM Method.

\section{RESULTS AND DISCUSSIONS}

It can be seen in TABLE I, TABLE II, and TABLE III that the main cause of the low OEE values is the low availability rate, because the performance and quality rates are already high. The OEE values in TABLE IV are much lower than the world class manufacturing standard of $85 \%$ [10].

OEE is an important measure that gives information regarding lost time and lost production [14]. The low availability rate is shown by the frequent machine stops because of the long time needed for the initial setting and preparation as well as frequent engine stop. The most time loss occurred when the machine is stopped because the operators conduct briefings, writing reports related to the machine, and rest. Moreover, huge time loss occurs in the cleaning activity. However, this activity is an activity that can not be avoided because the machine needs to be cleaned after use. The length of preparation time to take raw materials and packaging materials, as well as the time to ask for permission to field supervisors are also causing time loss that inhibits the production process. Setting the machine sometimes causes loss of time because of the breakdown caused by the error in some parts of the machine.

TABLE I. AVAILABILITY RATE

\begin{tabular}{|l|l|l|l|l|}
\hline \multicolumn{1}{|c|}{ Availability Losses } & \multicolumn{1}{|c|}{ July } & \multicolumn{1}{c|}{ August } & \multicolumn{1}{c|}{ Sept } & \multicolumn{1}{c|}{ Oct } \\
\hline Initial Setting (min) & 0 & 195 & 0 & 30 \\
\hline Preparation (min) & 705 & 900 & 705 & 450 \\
\hline Stop (min) & 1095 & 1635 & 1815 & 1395 \\
\hline Breakdown (min) & 60 & 315 & 1410 & 330 \\
\hline Maintenance (min) & 0 & 0 & 0 & 0 \\
\hline Cleaning (min) & 540 & 840 & 960 & 495 \\
\hline Other reason (min) & 0 & 135 & 315 & 330 \\
\hline $\begin{array}{l}\text { Total Availability } \\
\text { Losses (min) }\end{array}$ & 2400 & 4020 & 5205 & 3030 \\
\hline $\begin{array}{l}\text { Total Operation Time } \\
\text { (min) }\end{array}$ & 5985 & 10950 & 10980 & 6390 \\
\hline Availability Rate & $\mathbf{5 9 . 9 0 \%}$ & $\mathbf{6 3 . 2 9 \%}$ & $\mathbf{5 2 . 6 0 \%}$ & $\mathbf{5 2 . 5 8 \%}$ \\
\hline
\end{tabular}

TABLE II. PERFORMANCE RATE

\begin{tabular}{|l|l|l|l|l|}
\hline \multicolumn{1}{|c|}{ Performance Losses } & \multicolumn{1}{c|}{ July } & August & \multicolumn{1}{c|}{ Sept } & Oct \\
\hline Setting/Adjustment (min) & 0 & 0 & 75 & 0 \\
\hline Sorting (min) & 0 & 60 & 0 & 0 \\
\hline Deviation (min) & 0 & 0 & 0 & 0 \\
\hline Speed Losses (min) & 0 & 0 & 0 & 0 \\
\hline $\begin{array}{l}\text { Total Performance Losses } \\
\text { (min) }\end{array}$ & 0 & 60 & 75 & 0 \\
\hline $\begin{array}{l}\text { Total Operation Time } \\
\text { (min) }\end{array}$ & 5985 & 10950 & 10980 & 6390 \\
\hline Performance Rate & $\mathbf{1 0 0 \%}$ & $\mathbf{9 9 . 1 3 \%}$ & $\mathbf{9 5 . 0 6 \%}$ & $\mathbf{1 0 0 \%}$ \\
\hline
\end{tabular}

TABLE III. QUALITY RATE

\begin{tabular}{|l|c|c|c|c|}
\hline \multicolumn{1}{|c|}{ Yield } & July & August & Sept & Oct \\
\hline Output Actual (L) & $2,852,970$ & $5,461,170$ & $2,136,120$ & $2,520,390$ \\
\hline Output Theory (L) & $2,880,000$ & $5,520,000$ & $2,160,000$ & $2,538,000$ \\
\hline Quality Rate & $\mathbf{9 9 . 0 6 \%}$ & $\mathbf{9 8 . 9 3 \%}$ & $\mathbf{9 8 . 8 9 \%}$ & $\mathbf{9 9 . 3 1 \%}$ \\
\hline
\end{tabular}

TABLE IV. OVERALL EQUIPMENT EFFECTIVENESS RATE

\begin{tabular}{|c|c|c|c|c|}
\hline & July & August & Sept & Oct \\
\hline $\begin{array}{l}\text { OEE Rate } \\
\text { (AxPxQ) }\end{array}$ & $59.34 \%$ & $62.07 \%$ & $49.45 \%$ & $52.22 \%$ \\
\hline
\end{tabular}

Performance rate on the production machine, which is measured by the setting or adjustment and speed losses on the machine, indicates that the machines used in the production process has a fairly good performance. Quality rate of the machine is already high. The theoretical output almost matches the actual output. 


\section{A. Failure Mode and Effect Analysis}

The FMEA method is conducted to analyze the failure modes of the packaging materials. FMEA method is done to identify the cause of the rejection of each packaging material.
Ratings are given based on three variables: severity, occurrence and detection.

TABLE V. FAILURE MODE AND EFFECT ANALYSIS

\begin{tabular}{|c|c|c|c|c|c|c|c|c|}
\hline Component & $\begin{array}{c}\text { Failure } \\
\text { Mode }\end{array}$ & Failure Effect & $\mathbf{S}$ & Causes & $\mathbf{O}$ & Controls & D & RPN \\
\hline \multirow[t]{2}{*}{ Bottle } & Broke & $\begin{array}{l}\text { Hazard to the } \\
\text { operator }\end{array}$ & \multirow[t]{2}{*}{3} & \multirow{2}{*}{ Bottles intersect } & \multirow[t]{2}{*}{1} & \multirow{2}{*}{$\begin{array}{l}\text { Supervise the bottle } \\
\text { blowing process so that the } \\
\text { bottle does not stack up on } \\
\text { the conveyor }\end{array}$} & \multirow{2}{*}{2} & \multirow{2}{*}{6} \\
\hline & Crack & Not worth selling & & & & & & \\
\hline Cap & $\begin{array}{l}\text { The seal } \\
\text { broke }\end{array}$ & $\begin{array}{l}\text { The bottle is not } \\
\text { properly closed }\end{array}$ & 5 & $\begin{array}{l}\text { Placement of cap } \\
\text { does not fit so the } \\
\text { seal lock and caps } \\
\text { stacked and bottle is } \\
\text { not sealed properly }\end{array}$ & 6 & $\begin{array}{l}\text { Give more attention to } \\
\text { setting the machine, raise } \\
\text { the skills of operators with } \\
\text { training }\end{array}$ & 5 & 150 \\
\hline Sticker & Not precise & Not worth selling & 5 & $\begin{array}{l}\text { The bottle comes too } \\
\text { quickly or } \\
\text { incompatible } \\
\text { machine settings }\end{array}$ & 4 & $\begin{array}{l}\text { Paying attention to setting } \\
\text { and capacity of the } \\
\text { machine speed }\end{array}$ & 3 & 60 \\
\hline \multirow{2}{*}{ Box } & Exfoliate & Not worth selling & \multirow{2}{*}{3} & $\begin{array}{l}\text { Box overlaps and } \\
\text { stick to each other }\end{array}$ & \multirow{2}{*}{3} & \multirow{2}{*}{$\begin{array}{l}\text { Counseling the operator to } \\
\text { be more careful when } \\
\text { taking the box, check the } \\
\text { condition of the box when } \\
\text { it is received from supplier }\end{array}$} & \multirow{2}{*}{2} & \multirow{2}{*}{18} \\
\hline & Locking Loss & Bottle falls & & $\begin{array}{l}\text { The locking at the } \\
\text { bottom of the box } \\
\text { does not fit }\end{array}$ & & & & \\
\hline Silica & Cropped & $\begin{array}{ll}\begin{array}{l}\text { Silica } \\
\text { contaminating } \\
\text { products }\end{array} & \text { gel } \\
\text { the }\end{array}$ & 7 & $\begin{array}{l}\text { Setting machines is } \\
\text { incompatible with } \\
\text { the size of the silica }\end{array}$ & 8 & $\begin{array}{l}\text { Do the measurement on } \\
\text { silica to adjust machine } \\
\text { settings }\end{array}$ & 5 & 280 \\
\hline
\end{tabular}

FMEA analysis may help in improving the efficiency of the manufacturing process and the quality of product in order to decrease the number of defective products and reducing rework cost and time [5]. FMEA is made to analyze the high reject rate of the packaging material to help Company $\mathrm{X}$ resolve problems in a more focused and targeted way.

Based on the calculations in table $\mathrm{V}$, it can be seen that the silica gel component has the RPN value of 280 , which is the highest RPN amongst other components. With the severity grade of 7 and occurrence grade of 8 , it indicates that it has potentially fatal consequences and it often happens. This component should be closely monitored in the packaging process. The error in the cutting process of silica often occurs because of the difference in the size of the silica rolls.

The second highest RPN belongs to the cap component with RPN value of 150 . The failure often happens because these materials are processed fully by the packaging machine. Operators often only focus on running the machine without caring about the correctness of the settings and the output of those settings.

The third highest RPN belongs to the sticker component with RPN value of 60 . Reject stickers occur because the stickers are not correctly applied. If products with faulty stickers pass to the hands of consumers, there are no potentially fatal effects but it will affect customer satisfaction with the product.
The fourth highest RPN belongs to the box component with the RPN value of 18 . The failure is often caused by supplier error in stacking the boxes. The boxes impinge upon each other and stick to each other so that when the boxes are lifted, the paint coat of the boxes chipped.

The lowest RPN belongs to the bottle component. It rarely occurs and it has low severity. Moreover, it is easy to detect the problems relating to the bottle component before it happens.

\section{B. Fishbone Diagram}

Based on observations on the production process, a Fishbone diagram is developed. The results can be seen in Fig.1. In the packaging process, the fishbone diagram is made to see each of the variables that affect the loss of time that occurs when the production line is running. Fishbone diagram in Fig. 1 shows the variables that can or can not be controlled by the production department. Variables that can be controlled described by symbol $X$ while variable that can not be controlled described with symbol N. Variables that can not be controlled by the production department are the variables associated with external parties, such as suppliers. Variables that can be controlled by the production department are the variables that related with machine condition, operator skill, material placement, movement of the operator, and the replacement of product variations. The following are the important variables: 


\section{1) Machine's Condition}

Machine condition is one of the main aspects that support the packaging process. Optimal machines conditions highly affect the availability and performance rate value associated with the machine OEE values. On the production line, the machine used is composed of three main parts that are silica inserter, capsule filling, and capping the bottle. Each section of the machines will have the effect of stopping the process (line stop) as follows:

\section{a) Sensor condition on the machine (X1)}

Sensors are located on each part of the machine that serves to detect the position of the bottle on the conveyor is running. Sometimes, damage to the sensor will result in potentially fatal errors that cause the packaging process to be inhibited.

\section{b) Filling speed (X2)}

Production machine runs with manual settings set by the operator during the packaging process. Standard filling speed used in the packaging process is 40 bottles per minute (bpm). Sometimes, when the filling speed is increased, errors occurred caused by the conveyor that can not compensate for the speed of filling causing a lot of products falling out of the conveyor.

\section{c) Capping speed (X3)}

Capping machines is set manually by an operator with a setting of $40 \mathrm{bpm}$. Errors often happen in the cap placement process. When the caps are not properly installed on the bottle, the caps broke.

\section{d) Cutting of Silica Gel (X4)}

The cutting process of the silica gel uses two knives and a sensor on silica inserter machine. The packaging process often stops because of an error in cutting the silica gel causing granules of silica gel scatter out of the silica gel pocket and contaminate the product. The error occurs because of differences in the size of the silica gel rolls from the current supplier.

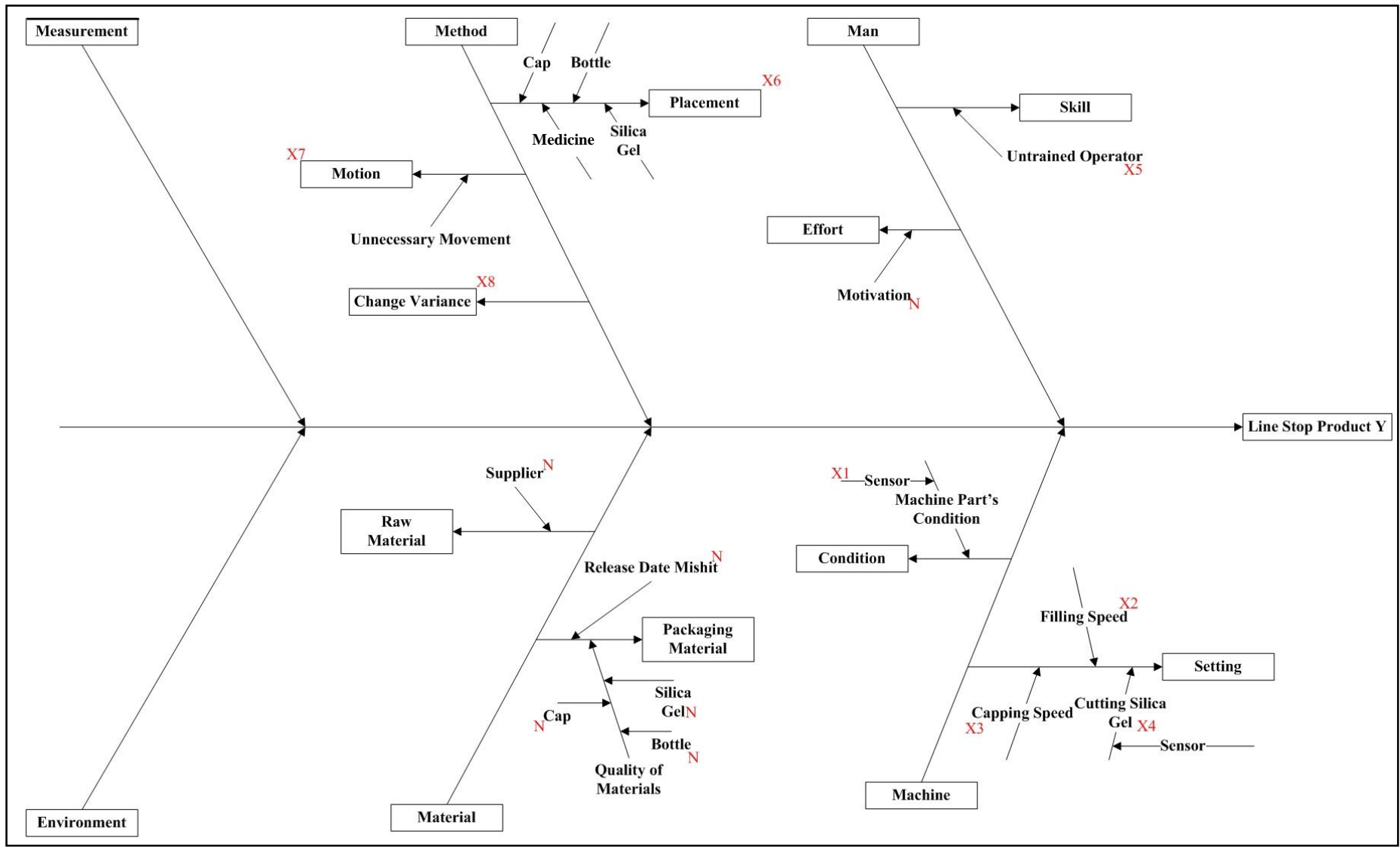

Fig. 1. Fishbone Diagram

\section{2) Operator's Skill (X5)}

Operator's skill affects the packaging process. Each operator has different level of skill causing differences in the length of time stops when the process is run by a different operator.

\section{3) Placement of the Material (X6)}

Duration of the production time is also affected by the placement of the material used in the process. In the production process, materials are placed in two different places. Medicine is placed in WIP (Work in Process) room near the packaging room. While the packaging materials such 
as bottles and cap placed on warehouse away from the packaging room. This hampers the packaging process.

\section{4) Operator's Movement (X7)}

Movements performed by the operator is quite effective, but the narrow space in the packaging area impedes operator to take action quickly when error occurs on the machine.

\section{5) Product Variation (X8)}

Production machines are used only for producing Product $\mathrm{Y}$ with several flavors variance. When a change of variety of flavors (for example, from strawberry to grape), it is necessary to do major cleaning process that takes a long time, around 3-4 hours. This process hampers the production process.

\section{Total Productive Maintenance}

Total Productive Maintenance (TPM) strategy that focuses on OEE demonstrates that using the production line status and all related information, operators and maintenance staff can work closely to generate more improvement suggestions and to provide well-functioning equipment, performance efficiency and availability of equipment [15].

Based on the discussions with the production department of Company $\mathrm{X}$, the plan for the application of TPM in improving the productivity and efficiency of the packaging process of Product $\mathrm{Y}$ consists of 5 of the 8 pillars of TPM:

\section{1) $5 \mathrm{~S}$}

$5 \mathrm{~S}$ Implementation is done by arranging the layout of secondary packaging to optimize the production process as follows.

Sort

Straighten

Eliminate chairs and objects that are not used in the production process. Eliminate plastic, paper and other packaging materials that are not used to provide trash.

Place packaging materials close to the operator to reduce non-added value when making the packaging process.

Shine Maintain the cleanliness and the location of the device and always keep the environment clean.

Standardize Make standardized procedures and arrangements that will be applied by every operator in the packaging area.

Sustain Keeping and making a habit of $5 \mathrm{~S}$ implementations in order to maintain and optimize packaging processes.

The success of $5 \mathrm{~S}$ implementation depends on the level of support from the top management, continuous benchmarking activities with other companies, and involvement of all employees [16].

\section{2) Autonomous Maintenance}

Provide trainings to operators in overcoming simple damage and errors in the machine. Furthermore, it is suggested to change the error log interval from 15 minutes to 5 minutes in order to avoid roundings in the time records. The error log contains time records of breakdowns, stops, and other errors encountered during production process.

\section{3) Planned Maintenance}

Planning preventive maintenance in order to make machines in good condition during the production process in progress. To offset the production process, Company X's preventive maintenance process is set to be held every two months. However, the stop line often shows that there are errors that arise so it is recommended that the preventive maintenance is done more often. In addition, it is suggested that their Output Nozzle (mouthpiece filling) be wider so the products can descend smoothly to the bottle. Based on the observations of the condition of the machine, the vibrator part of the filling machine needs to be replaced because it is not functioning properly.

\section{4) Quality Maintenance}

Based on data observations and discussions with the production department, the number of rejects of packaging materials is below $2 \%$ of the yield of the production, which is the maximum reject percentage that is tolerated by the company. However, sudden significant rise in the number of rejects sometimes happens. Therefore, Company $\mathrm{X}$ will conduct research on the causes of the sudden rise of reject materials.

\section{5) Training}

Trainings should be provided not only by expert trainers, but also from one another. The purpose is to foster curiosity amongst operators to learn from others and teach others. One of the training topic that will be conducted is reject detection in primary packaging. In this training, operators can learn to detect characteristics of reject material in the secondary packaging.

\section{CONCLUSION AND SUGGESTIONS}

Based on the observation, some conclusions can be obtained as follows.

- The average Overall Equipment Effectiveness value of production machine during July - October 2015 was $55.76 \%$, which illustrate that the condition of the machine is not ideal and still require improvement.

- Based on the FMEA, the highest RPN is the silica gel component. This happens because differences in size of the silica gel rolls acquired from the current supplier. Therefore, it is suggested to buy silica gel rolls from another supplier.

- The main cause of the stop line on the production process Product $\mathrm{Y}$ are condition of sensor on the machine (X1), the speed of filling (X2), capping speed (X3), cutting silica gel (X4), operator skill (X5), placement material (X6), the movement of the operator (X7), the change of product variations (X8).

- Total Productive Maintenance pillars that can be used to improve the OEE of the packaging process is $5 \mathrm{~S}$, autonomous maintenance, planned maintenance, quality maintenance, and training. 


\section{References}

[1] Kumar SV, Mani VGS, Devraj N. Production Planning and Process Improvement in an Impeller Manufacturing Using Scheduling and OEE Techniques. Procedia Materials Science. 2014; 5: 1710-1715.

[2] Ahire CP, Relkar AS. Correlating Failure Mode Effect Analysis (FMEA) \& Overall Equipment Effectiveness (OEE). Procedia Engineering. 2012; 38: 3482-3486.

[3] Dobrusskin C. On the Identification of Contradictions using Cause Effect Chain Analysis. Procedia CIRP. 2016; 39: 221-224.

[4] Hegde HG, Mahesh NS, Doss K. Overall Equipment Effectiveness Improvement by TPM and $5 \mathrm{~S}$ Techniques in a CNC Machine Shop. SASTECH. 2009; 8(2): 25-32.

[5] Parsana TS, Patel MT. A Case Study: A Process FMEA Tool to Enhance Quality and Efficiency of Manufacturing Industry. Bonfring International Journal of Industrial Engineering and Management Science. 2014; 4(3): 145-152.

[6] Badariah N, Surjasa D, Trinugraha Y. Analisa Supply Chain Risk Management Berdasarkan Metode Failure Mode and Effect Analysis (FMEA). Jurnal Teknik Industri. 2012; 2(2): 110-118.

[7] Firdaus R, Sukmono T, Akbar A. Perbaikan Proses Produksi Muffler dengan Metode FMEA pada Industri Kecil di Sidoarjo. TEKNOLOJIA. 2015; 5: 83-88.

[8] Syukron A, Kholil M. Six Sigma: Quality for Business Improvement. Yogyakarta: Graha Ilmu; 2013.
[9] Almeanazel OT. Total Productive Maintenance Review and Overall Equipment Effectiveness Measurement. Jordan Journal of Mechanical and Industrial Engineering. 2010; 4(4): 517-522.

[10] Goriwondo WM, Mhlanga S, Kazembe T. Optimizing a Production System Using Tools of Total Productive Maintenance. Paper presented at the 2nd International Conference on Industrial Engineering and Operations Management; Kuala Lumpur; 2011 Jan 22-24.

[11] Rahmad, Pratikto, Wahyudi S. Penerapan Overall Equipment Effectiveness (OEE) dalam Implementasi Total Productive Maintenance (TPM). Jurnal Rekayasa Mesin. 2012; 3(3): 431-437.

[12] Wakjira MW, Singh AP. Total Productive Maintenance: A Case Study in Manufacturing. Global Journal of Researches in Engineering. 2012, 12(1): 25-32.

[13] Khokhar P, Dhankar S. Factors Affecting the Losses of the TPM in Industries. International Journal of Research in Engineering \& Applied Sciences. 2014; 4(3): 151-160.

[14] Pintelon LMYA, Muchiri PN. Performance Measurement Using Overall Equipment Effectiveness (OEE): Literature Review and Practical Application Discussion. International Journal of Production Research. 2008; 46(13): 3517-3535.

[15] Lazim HM, Salleh MN, Subramaniam C, Othman SN. Total Productive Maintenance and Manufacturing Performance: Does Technical Complexity in the Production Process Matter. International Journal of Trade, Economics and Finance. 2013; 4(6): 380-383.

[16] Hegde HG, Mahesh NS, Doss K. Overall Equipment Effectiveness Improvement by TPM and $5 \mathrm{~S}$ Techniques in a CNC Machine Shop. SASTECH. 2009; 8(2): 25-32. 